\title{
Islamofobia e elementos fascistas no discurso de Olavo de Carvalho e do Movimento Mídia Sem Máscaras (MSM)
}

\author{
Natalia Cruz \\ Universidade Federal Fluminense, Brasil \\ (i) https://orcid.org/0000-0002-5797-2156 \\ ndrc@globo.com
}

\section{Introdução}

O Brasil vem sendo palco de diversos movimentos de extrema-direita nas últimas décadas do século XX e início do século XXI. A reestruturação do capitalismo, a fragmentação da classe trabalhadora, enfraquecendo sua identidade de classe, e a instabilidade econômica e social que coloca as classes médias em uma situação de insegurança e predispostas a medos coletivos socialmente construídos, contribuíram para que o terreno político e social brasileiro torne-se fértil para o surgimento de movimentos sociais extremistas situados à direita do espectro político, com discursos elaborados em torno da ideia de inimigo e de nacionalismo extremado.

O presente trabalho estuda o movimento Mídia Sem Máscara 
(MSM), criado e liderado por Olavo de Carvalho, que faz uso das redes sociais para difundir sua visão de mundo e suas narrativas sobre os problemas brasileiros e mundiais, com o objetivo de alcançar a opinião pública e persuadi-la a aderir às suas propostas discriminatórias e excludentes de organização da sociedade brasileira.

O aspecto de seu discurso a ser analisado será a islamofobia, apreendendo como o discurso islamofóbico aparece em suas narrativas e se articula com uma visão fascista de mundo, ligando-se a um projeto político excludente e autoritário que, no entanto, usa a ideia de neutralidade e objetividade para ocultar a ideologia de extrema-direita inerente ao seu discurso. Será abordada também a simetria do seu discurso com o chamado neoconservadorismo norte-americano, apresentando as influências dessa corrente de pensamento nas ideias do movimento e do seu líder.

Para abordar o discurso do Mídia Sem Máscara e de seu líder Olavo de Carvalho, farei uso da metodologia da análise crítica do Discurso, desenvolvida historicamente como prática social transformadora da sociedade, possibilitando aos analistas um papel de intervenção social na realidade por meio de suas análises. Ao desnudar as ideologias implícitas nos discursos dominantes, tal metodologia contribui para demonstrar a função social de determinados discursos, qual seja, a manutenção de relações sociais, econômicas e políticas que estruturam a dominação das classes favorecidas sobre o conjunto da população. (KRESS, 1990, p. 85).

Para o presente trabalho, será usada a contribuição de Gramsci, através dos conceitos de hegemonia e guerra de posição, para compreender a difusão dos discursos do MSM através das redes sociais como forma de conquistar a hegemonia de suas ideias e de seu modelo de sociedade junto à opinião pública, fortalecendo a posição política, 
econômica e social das classes dominantes.

A análise será baseada na perspectiva do linguista britânico Norman Fairclough (2001), cujo método se enquadra na Teoria Social do Discurso, analisando-se as relações entre o discurso e outros elementos da prática social. Para ele, um discurso é simultaneamente um texto, uma prática discursiva e uma prática social, possuindo uma natureza dialética, pois o discurso constitui a realidade social e é também constituído por ela.

Os conceitos gramscinianos de hegemonia e guerra de posição (GRAMSCI, 1988) serão utilizados para a compreensão dos objetivos do MSM na difusão dos discursos produzidos em seu site. Serão apontados também os elementos fascistas do discurso do movimento em questão, sendo a metodologia da análise crítica do discurso e os conceitos de Gramsci extremamente úteis para a desconstrução do discurso de caráter fascista do Mídia Sem Máscara, contribuindo assim para o fortalecimento dos ideais democráticos na sociedade brasileira.

Para tanto, é extremamente importante uma discussão sobre os conceitos de fascismo, autoritarismo, direita e extrema direita, temas bastante controversos e sujeitos a vários debates no campo das ciências sociais e da história. O discurso do MSM e de Olavo de Carvalho possui alguns elementos pertencentes à visão de mundo fascista, podendo ser identificado com o campo político da extrema-direita.

\section{Direita, Autoritarismo, Fascismo e Neofascismo}

Segundo Schurster, Lapsky \& Silva (2014, p. 9), a “direita” é composta por uma variedade de posições e tendências. Existem aqueles que aderem ao sistema de valores e às instituições representativas das democracias liberais, mas com forte conteúdo antissocial e regressivo 
- como o corte de direitos sociais e de conquistas políticas -, enquanto outros propõem a supressão da ordem representativa e abandonam o conceito de "liberdade" enquanto um símbolo de sua ação e propaganda políticas. Existem os que adotam perspectivas xenofóbicas e racistas, podendo chegar ou não a um projeto político de caráter fascista.

O que une as diversas tendências do campo da direita é a defesa da ordem social dominante e do status quo econômico, com preservação do sistema de propriedade privada dos meios de produção e dos interesses econômicos dos grupos dirigentes em face do conjunto organizado e popular da sociedade. A direita é, em sua maioria conservadora, mas podemos encontrar também tendências reacionárias, que apresentam um saudosismo em relação a épocas anteriores, representadas de forma idílica e mítica. ${ }^{1}$

Ainda segundo Schurster, Lapsky \& Silva (2014, p. 10), não há uma essência única no campo da direita, embora alguns temas apareçam em praticamente todas as tendências direitistas - como a supressão de direitos sociais, a liberdade do uso de armas e a diminuição dos direitos políticos. No que diz respeito ao papel do Estado, por exemplo, os segmentos da direita tradicional ou da direita fundamentalista veem o Estado como um ente “totalitário”, incompetente e perdulário na gestão da coisa pública e seu tamanho "excessivo” como ameaça à "liberdade" do indivíduo. Já para a direita mais ligada ao fascismo clássico, e mesmo a algumas ditaduras militares clássicas, o Estado é um instrumento fundamental para a prosperidade e realização dos objetivos “nacionais”, incluindo-se o dirigismo econômico.

A extrema-direita, seja de caráter fascista ou ligada às formas auto-

\footnotetext{
${ }^{1}$ Para aprofundamento da diferença entre conservadores e reacionários, ver Silva (2000).
} 
ritárias tradicionais da direita, é uma forma de expressão das mais radicais de um submundo que afirma e legitima sua presença na sociedade através da prática da violência, seja física ou verbal. “A ressurgência dos fascismos está ligada ... a uma questão central que identificamos como sendo a alteridade” Schurster, Lapsky \& Silva (2014, p. 10). Tais tendências negam a possibilidade da diferença e da pluralidade.

Há os autores que percebem o liberalismo como a ideologia que marcou os limites e os graus de intensidade do espectro político da direita. Para Crespo (2014, p. 18-19), a direita distingue-se em dois pontos: a tensão entre liberdade e autoritarismo e entre livre mercado e estatismo. O liberalismo é uma ideologia fundamentada centralmente no individualismo e na fobia pelo Estado. Em termos históricos, o liberalismo afirmou-se como a ideologia contrária à monarquia absoluta propondo limites à ação estatal sobre o indivíduo. Partindo desta visão individualista e da concepção negativa de liberdade, o liberalismo fundamentou sua ideologia em uma "moral sobre o político" para proteger três direitos considerados como naturais e inalienáveis: o direito à vida, o direito à propriedade e o direito à liberdade (DWORKIN, 1985). O liberalismo seria então uma ideologia que propõe uma forma de governo representativo que respeita o indivíduo, as leis e o Estado de Direito (CRESPO, 2014, p. 19). A direita não-liberal situase então no campo da extrema-direita, defendendo regimes autoritários e/ou intervenção do Estado na vida individual, situando-se neste campo tendências fundamentalistas religiosas que pretendem impor regras de comportamento moral, os movimentos xenofóbicos, racistas e/ou fascistas. Ressalte-se ainda que um movimento ou regime de extrema-direita não necessariamente é antiliberal na economia, havendo combinações de liberdade econômica com não-liberdade na esfera civil e política. 
A extrema-direita pode ser de caráter tradicional, como é o caso de ditaduras militares clássicas, ou de caráter fascista. O conceito de fascismo, portanto, define uma tendência da direita que não pode ser compreendida com o simples conceito de autoritarismo. ${ }^{2}$ Inicialmente, o termo "fascismo" era designado para definir o movimento político fundado por Benito Mussolini, em Milão, em 1919, cuja expressão concreta eram os chamados "fasci di combattimento", com a palavra fascio significando feixe e união, símbolo da autoridade dos magistrados romanos. Os fasci di combattimento eram grupos paramilitares do partido fascista, formado por militantes que exerciam atos violentos contra os inimigos do movimento. Posteriormente, o termo passou a designar outros diversos movimentos e partidos nacionalistas de extrema-direita, caracterizados por estruturas fortemente hierarquizadas, centradas num líder, em torno de ideias autoritárias, antili-

\footnotetext{
${ }^{2}$ Segundo Bobbio (1995, p. 95-97), são chamados de autoritários regimes que privilegiam a autoridade governamental e diminuem o consenso, concentrando o poder político nas mãos de uma única pessoa ou órgão, relegando a segundo plano as instituições representativas ou até mesmo aniquilando-as. A autoridade política, neste caso, é condicionada por uma estrutura política hierárquica baseada na ideia de desigualdade entre os homens e exclui ou reduz ao mínimo a participação do povo no poder, empregando meios coercitivos contra os opositores. Autoritarismo é diferente de totalitarismo, pois neste o princípio hierárquico não é um instrumento da ordem, mas de mobilização total da nação numa luta ilimitada contra outras nações ou seus inimigos internos. O totalitarismo busca o consenso e pretende o domínio total pela via tanto da coerção como do convencimento das massas. Os regimes fascistas seriam tendencialmente totalitários. Mas existem análises que conceituam o totalitarismo partindo dos pressupostos liberais, construindo abstrações teóricas exatamente opostas aos valores do liberalismo. Um exemplo é a obra de F. Neumann (1969, p. 268-70), que enumera o que seria para ele os cinco fatores de uma ditadura totalitária: estado policial x estado de direito (força $\mathrm{x}$ lei), poder concentrado x poder difuso (concentração x difusão), partido estatal monopolista x pluralidade partidária (monopólio x pluralismo), controles sociais totalitários x controles sociais pluralistas (Estado x liberdade) e presença do terror como ameaça ao indivíduo (violência x razão do indivíduo). Elabora-se então uma visão dicotômica que exalta o Estado liberal como o melhor dos mundos, onde predominaria o reino da lei, da razão e da liberdade, enquanto no seu contrário reinaria a opressão e a violência.
} 
berais, antidemocráticas e anticomunistas. Assim, o termo virou um conceito que abrange um conjunto de manifestações políticas que apenas na aparência se diferenciavam, e que compartilhavam elementos ideológicos comuns (FALCON, 1991).

Konder (1977) reafirma que o conceito de fascismo não se reduz aos conceitos de ditadura ou autoritarismo, pois nem todo movimento ou regime autoritário é fascista. O fascismo pertence ao gênero da direita, sendo uma espécie de direita diferente das direitas tradicionais. O fascismo pretende mobilizar as massas em torno de um ideal comum, por isso não aceita o relativismo absoluto, pois ele é incapaz de armar os homens para o combate e impede a formação de bases sólidas para as convicções apaixonadas que devem mover o engajamento das massas. O fascismo precisa de um princípio sagrado, posto acima de qualquer discussão e dúvida. Esse princípio é o mito da Pátria, baseado em uma unidade fictícia, e não na nação real com conflitos e contradições, havendo a repressão ao diferente e ao que não faça parte da identidade nacional cultuada. O fascismo prega a união das classes sociais, e não o seu conflito, e arregimenta adeptos em todos os setores sociais.

Os debates acerca das bases sociais dos movimentos fascistas são permeados de divergências. Dentro do campo marxista, os autores se dividem entre os que relacionam o fascismo com o grande capital e os que acentuam a participação das camadas médias da sociedade. A historiografia marxista tende a associar a ascensão dos fascismos com a crise do capital monopolista em suas dificuldades para desenvolver extensiva e intensivamente a exploração da força de trabalho. Dessa forma, o fascismo teria servido para esmagar as organizações independentes da classe trabalhadora, atraindo parte dela e dos setores médios, cujo principal beneficiado teria sido o grande capital. As 
análises mais dogmáticas e reducionistas estabelecem uma relação direta capital fascismo, como se este tivesse sido criação dos grandes setores capitalistas. Autores marxistas contribuíram também para relativizar essas análises, enfatizando que originalmente os fascismos foram movimentos da pequena burguesia que posteriormente foram instrumentalizados e apoiados pelos grandes capitalistas por não verem mais os partidos burgueses tradicionais como garantidores da ordem do capital. ${ }^{3}$

Um dos autores que inovou nos estudos sobre o fascismo no campo marxista foi Palmiro Togliatti, que em sua obra Lições sobre o Fascismo, escrita em 1935, superou a fórmula simplista elaborada pela Internacional Comunista, em novembro de 1935, segundo a qual o fascismo seria apenas "uma ditadura terrorista aberta dos elementos mais reacionários, mais chauvinistas e agressivos do capital financeiro” (RAGIONIERI, 1976, p. 742-743). ${ }^{4}$ Tal definição, além de não considerar o papel das massas no processo, não contribuía para diferenciar o fascismo das demais ditaduras tradicionais da burguesia. Togliatti enriqueceu então a definição de fascismo afirmando que ele é também um regime reacionário de massas (RAGIONIERI, 1976).

Togliatti percebeu que o fascismo, além de fazer uso da repressão e da violência, também realizava uma política de massas, sendo o Partido Nacional Fascista italiano um “partido de novo tipo” da burguesia, um partido de massas (VACCA, 1974, p. 231). Nesse sentido, Togliatti se aproximaria da reflexão de Antônio Gramsci - a

\footnotetext{
${ }^{3}$ Uma obra fundamental sobre as principais teorias explicativas do fascismo é a de Renzo de Felice (1976).

${ }^{4}$ Com base nessa definição, a Internacional Comunista adotou a teoria do "social fascismo” no VI Congresso em 1928, afastando a questão do caráter de massas do fascismo por alguns anos. Segundo esta teoria, a social-democracia seria um "irmão gêmeo" do fascismo, por também servir ao capital monopolista. Tal tese foi desconstruída por vários autores, entre os quais Trotsky (2019) e Poulantzas (1978).
} 
qual ele, inclusive, desconhecia -, desenvolvida em seus Cadernos do Cárcere, à medida que abordava a prática fascista de "obtenção do consenso" e não somente da "imposição por coerção” e por apontar para as relações estabelecidas entre o Estado fascista e as organizações de massa, entre elas o próprio partido fascista e os sindicatos corporativos (MONDAINI, 2003).

Togliatti (1974, p. 111) mostra que a ditadura fascista constrói um movimento de massa organizando a burguesia e a pequena burguesia, esforçando-se para levar as massas às suas organizações, ligando-as ao aparato da ditadura. Neste raciocínio, percebe-se em seu trabalho a revelação da estratégia que Gramsci vai definir como "guerra de posição" ou "luta por hegemonia nas fronteiras da sociedade civil” (GRAMSCI, 1989).

Gramsci também foi um dos grandes estudiosos do fascismo, tendo sido ele mesmo prisioneiro do fascismo italiano. O historiador estadunidense Walter Adamson (1980) aponta que Gramsci evoluiu em sua análise sobre o fascismo quando, em sua obra Cadernos do Cárcere (escrita na prisão sob o regime de Mussolini), desenvolve os conceitos de crise de hegemonia/crise orgânica, cesarismo e revolução passiva. ${ }^{5}$

Segundo Melo (2016, p. 128-130), um importante aspecto da teoria política de Gramsci é abordar o processo hegemônico como uma relação dialética entre elementos de direção com os de domínio, consenso e coerção. É possível obter o consenso “espontâneo” de amplas camadas da população, enquanto a coerção é exercida sobre os grupos ou setores sociais que resistem ou sobre a sociedade como um todo nos momentos de crise em que o consenso “espontâneo” é quebrado.

\footnotetext{
${ }^{5}$ Para discussão mais aprofundada desses conceitos na obra de Gramsci, ver Melo (2016).
} 
O fascismo seria então uma forma de regime que combina alta dose de coerção com boa dose de consenso.

A importância da discussão conceitual sobre o fascismo reside no esclarecimento quanto à sua natureza social, às diferenças entre os movimentos fascistas (inicialmente dominados pelos setores pequenoburgueses) e os regimes fascistas (quando o grande capital passa a ser o principal beneficiado pelas políticas do Estado fascista) e à sua diferenciação frente aos movimentos e regimes autoritários de direita tradicionais, que se limitam à coerção e não mobilizam as massas. Nesse sentido, é muito importante a obra de Poulantzas (1978), que relaciona o processo de fascização das sociedades italiana e alemã a uma crise política específica, envolvendo as frações burguesas em sua dificuldade de obter a hegemonia sobre o bloco no poder, resultando na reorganização deste bloco sob a hegemonia do capital monopolista e financeiro. O autor aponta alguns elementos que fazem parte deste processo de fascização, dentre eles, a ruptura entre as classes sociais e os partidos que as representam, uma crise ideológica generalizada e a penetração da ideologia pequeno-burguesa na classe operária.

O movimento Mídia Sem Máscara é formado por elementos da pequena burguesia, como jornalistas, advogados, professores, psiquiatras etc., que apresentam em seu discurso elementos da mentalidade fascista (teorias conspiratórias, aversão à diversidade política e étnico cultural, construção de inimigos internos e externos, nacionalismo etc.), conforme veremos adiante, e se preocupam em mobilizar vastos setores da sociedade através das redes sociais em um movimento de confluência entre a propaganda e a publicidade (Patschiki, 2012, p. 123), em uma iniciativa de produção de consenso em torno de ideias que servem aos interesses dos setores dominantes da grande burguesia, assim como possuem uma rede extrapartidária associada a vários 
aparelhos privados de hegemonia da grande e pequena burguesia. Por essas relações e por suas ideias, Patschiki (2012, p. 17-18) afirma serem "prepostos, funcionários da classe dominante, que arrogam um poder que não detêm, mas que mesmo assim encarnam”.

Seus vínculos com elementos ideológicos do fascismo não significam que reproduzam toda a ideologia fascista e a forma de organização dos fascismos clássicos (aqueles situados entre o período entreguerras). Nestes, o antiliberalismo era voltado para todos os aspectos, políticos, sociais e econômicos, pois a economia era corporativa com forte intervenção do estado na organização dos diversos elementos produtivos com vistas a garantir a reprodução ampliada de acumulação de capital. Nos chamados neofascismos, há uma combinação entre defesa do liberalismo econômico com um antiliberalismo político e social. A liberdade da iniciativa privada no mercado é defendida, mas não a liberdade individual em questões morais e comportamentais e as liberdades políticas, visto que em seu discurso, os adversários são tratados como inimigos e não como forças legítimas na disputa política, revelando-se assim um caráter autoritário desse movimento, embora procurem mascarar seu autoritarismo atuando no sistema liberal democrático.

Portanto, este artigo não advoga a tese epocal sobre o fascismo, segundo a qual o fascismo seria produto de uma dada época histórica situada no período entreguerras e indissociável da crise econômica, política e social do período, sendo as consequências da primeira guerra mundial um dos fatores chave para a explicação da ascensão dos movimentos e regimes fascistas. Por essa visão, os fascismos não ressurgiriam em outros períodos históricos, pois aquela conjuntura específica não se repetirá. Fazem parte desta concepção historicista do fascismo pensadores como Renzo de Felice (1976) e Ernest Nolte 
(1963), entre outros.

Consideramos que o fascismo pode ressurgir em outros contextos históricos, pois atualmente há vários movimentos chamados neofascistas, que advogam o espírito e a essência do fascismo, embora não reproduzam exatamente a forma de organização e todo o ideário dos fascismos clássicos. Segundo Silva (2003), o fascismo não é um movimento morto, pertencente à história e sem qualquer papel político contemporâneo. A historiografia pós anos 1980 apresenta análises mais conceituais, que veem o fascismo como uma possibilidade da moderna sociedade de massas, e não apenas de um período histórico determinado. Seria possível então falar de um modelo a-histórico e fenomenológico do fascismo.

A definição mais apropriada do que seja fascismo foi dada por Robert Paxton, e podemos encontrar movimentos desse tipo nas sociedades atuais. O fascismo é:

uma forma de comportamento político marcada por uma preocupação obsessiva com a decadência e a humilhação da comunidade, vista como vítima, e por cultos compensatórios da unidade, da energia e da pureza, nas quais um partido de base popular formado por militantes nacionalistas engajados, operando em cooperação desconfortável, mas eficaz com as elites tradicionais, repudia as liberdades democráticas e passa a perseguir objetivos de limpeza étnica e expansão externa por meio de uma violência redentora e sem estar submetido a restrições éticas ou legais de qualquer natureza (PAXTON, 2007, p. 358-359).

Os chamados neofascistas defendem o neoliberalismo, saindo da proposta do fascismo clássico de cunho corporativista e intervencionista do Estado. ${ }^{6}$ Calil (2018) aponta que a associação entre fascistas

${ }^{6}$ É importante atentar para o fato de que o caráter intervencionista do Estado nos fascismos clássicos não significou estatização de empresas, mas sim regulação dos conflitos de classes, com vistas a assegurar a hegemonia da fração do capital 
e neoliberalismo já existia entre os integralistas do pós $-1945^{7}$ no Brasil e que esse precedente integralista revela as formas específicas que o fascismo assume para se adaptar a diferentes contextos políticos, seja apresentando um compromisso “democrático” mas esvaziando o sentido do termo, seja incorporando uma perspectiva econômica neoliberal.

Essa observação é útil para visualizarmos o MSM como um movimento que defende ao mesmo tempo elementos do fascismo e também do neoliberalismo, assim como do neoconservadorismo norteamericano. $^{8}$

\section{A Teoria Social do Discurso}

É importante abordar como Fairclough concebe a teoria social do discurso, já que a sua metodologia será empregada na análise do discurso de Olavo de Carvalho. Fairclough inspirou-se na Linguística Sistêmica Funcional (LSF) desenvolvida por M. Halliday (1991), que vê a linguagem humana como dotada de funções sociais, havendo três macrofunções que atuam simultaneamente nos textos: ideacional, interpessoal e textual. A Ideacional seria a representação da experiência, refletindo a "realidade" na língua, ou seja, são as representações sobre a realidade. A função interpessoal seria o uso da linguagem na interação social, a língua como ação e como expressão de relações pessoais e sociais. Já a função textual diz respeito aos aspectos semânticos,

monopolista e financeiro do bloco no poder. Ver Poulantzas (1978).

${ }^{7} \mathrm{O}$ integralismo foi um movimento fascista surgido no Brasil em 1932, liderado por Plínio Salgado. Após 1945, adotou o nome de Partido de Representação Popular (PRP) e passou a adaptar o discurso ao novo contexto histórico, inclusive defendendo a pauta neoliberal.

${ }^{8} \mathrm{~A}$ relação com os neoconservadores norte-americanos será abordada no decorrer da análise do discurso do movimento. 
gramaticais e estruturais presentes no texto e que possuem um valor funcional.

Fairclough recontextualizou a LSF de Halliday, alterando alguns dos seus pontos. Ele mantém a função ideacional, mas cinde a função interpessoal em função relacional e função identitária. A primeira seria "como as relações sociais entre os participantes do discurso são representadas e negociadas" e a segunda "relaciona-se aos modos pelos quais as identidades sociais são estabelecidas no discurso" (FAIRCLOUGH, 2001, p. 92). Quanto à função textual, Farclough a incorpora ao significado acional, pois não distingue uma função 'textual' separada, mas a incorpora à ação (FAIRCLOUGH, 2003, p. 27).

Para Farclough, o discurso é a intermediação entre o texto e os eventos (ou a realidade), sendo uma prática social que expressa modos de agir, de representar e de ser. O significado acional aproximase da função relacional da linguagem, porque o texto é um modo de interação em eventos sociais e a ação através do texto questiona ou legitima relações sociais e de poder. A questão da intertextualidade e da interdiscursividade também é levada em conta no significado acional do texto. O significado representacional relaciona-se com a função ideacional porque enfatiza a representação da realidade, enquanto o significado identificacional diz respeito à construção de identidades no discurso, relacionando-se, portanto, com a função identitária.

O texto será percebido como uma das manifestações da linguagem, vista como essencialmente interativa, e que possui objetivos e fins a serem atingidos, já que se direciona ao outro, tendo uma perspectiva persuasiva e argumentativa. Partindo do pressuposto de que o discurso é baseado em um suporte ideológico, o conceito de ideologia mais especificamente o de John Thompson (2002) - será de extrema importância na compreensão do discurso do MSM, já que a linguagem 
é determinada em última instância pela ideologia, não havendo uma relação direta entre as representações sobre a realidade e a língua. Assim, analisar um discurso é compreender não somente o que o texto diz e como ele diz, mas também porque ele diz o que diz.

\section{Quem são Olavo de Carvalho e o Mídia Sem Máscara}

O Mídia Sem Máscara foi fundado em 2002, tendo como principal instrumento de divulgação de suas ideias a rede mundial de computadores. Localizado no site midiasemmascara.org, tem como fundador e editor-chefe Olavo de Carvalho (oriundo de uma família da nova pequena burguesia brasileira), que possui um site próprio, www.olavodecarvalho.org, denomina-se filósofo e ministra cursos no Seminário de Filosofia - o qual também possui um site, www.seminariodefilosofia.org. Olavo de Carvalho preside o The Inter-American Institute (theinteramerican.org), integrado, segundo o próprio, por intelectuais “de alto calibre dos EUA e da América Latina”. 9

O MSM foi fundado com o objetivo de "denunciar” o que chamam de "viés esquerdista” da mídia brasileira, que esconderia ou distorceria ideias e notícias. Assim, o site se pretende "sem máscara”, ou seja, divulgaria notícias sem distorções, apresentando-se como "objetivo" e "neutro", imagem esta totalmente inverídica pelo viés direitista das narrativas de seus membros.

A filiação ideológica do MSM pode ser percebida pelos links existentes em seu facebook para páginas do Instituto Mises Brasil (que defende as ideias neoliberais no mundo) e de Jair Messias Bolsonaro

\footnotetext{
${ }^{9}$ Informações retiradas do site midiasemmascara.org. Acesso em agosto de 2017. O movimento possui também Facebook (ptbr.facebook.com), Twitter (twitter.com) e Youtube (www.youtube.com).
} 
(famoso político brasileiro de origem militar, eleito à Presidência do Brasil nas eleições de outubro de 2018, sendo o principal representante das ideias de extrema-direita no país e defensor dos regimes militares instituídos no Brasil após o golpe de 1964). Assim, o MSM conjuga a defesa do neoliberalismo na economia e do conservadorismo de caráter autoritário na política e na sociedade.

Lucas Patschiki (2012) discorre sobre os intelectuais que compõem o movimento e analisa o MSM no período de 2002 a 2011. Segundo o autor, Olavo de Carvalho criou o MSM para agrupar vários intelectuais de direita em torno do anticomunismo, no contexto das eleições presidenciais de 2002 em que Luiz Inácio Lula da Silva, do Partido dos Trabalhadores (PT), foi eleito para o cargo pela primeira vez. Carvalho chegou a ser filiado ao Partido Comunista Brasileiro $(P C B)$ e afirma ter abandonado o partido em 1968 por discordar da luta armada, afirmação esta sem sentido, pois os que abandonavam o partido nesta época o faziam para entrar na luta armada, e não por serem contra essa forma de luta (PATSCHIKI, 2012, p. 27).

No final da década de 1980, passou a se dedicar mais ativamente à Filosofia (embora não tenha concluído nenhum curso superior na área), criando cursos permanentes, os chamados Seminários de Filosofia, época em que se firmou como intelectual “de certo renome”. Porém, na imprensa, Carvalho emergiu no espaço deixado pela morte de Paulo Francis, em 1997, período em que a grande mídia defendia ostensivamente o neoliberalismo, fazendo parte dessa rede o Jornal do Brasil, O Globo, a Folha de São Paulo e O Estado de São Paulo. Em 1996, lançou o livro $O$ imbecil coletivo: atualidades inculturais brasileiras pela Editora da UniverCidade do Rio de Janeiro, foi autor de vários livros sobre Astrologia, Política e Filosofia e, nos anos 2000, trabalhou em vários jornais, revistas e editoras, como O Globo, Zero 
Hora, Jornal do Comércio e Jornal do Brasil. (PATSCHIKI, 2012, p. 42-43)

O site próprio de Olavo de Carvalho, por sua vez, foi lançado em 1998, quando passou a atuar intensivamente nas redes sociais. Já em 2002, o Mídia Sem Máscara é fundado e, através dele, Carvalho passa a aglutinar em torno de si vários intelectuais, sendo um poderoso meio de unificação ideológica e organizacional da extrema-direita brasileira (PATSCHIKI, 2012, p. 46).

Em 2005, Carvalho foi demitido de diversos jornais e revistas em que trabalhava - entre eles O Globo e Zero Hora -, e passou a viver do Jornal do Comércio, mantido pela Associação Comercial de São Paulo (ACSP). Depois das demissões, ele mudou-se para os EUA, residindo em Richmond, Virginia, como correspondente do Diário do Comércio. (PATSCHIKI, 2012, p. 47)

Carvalho fundou também o Instituto Olavo de Carvalho (IOC), em 2009, que se tornou um importante espaço de formação ideológica de futuros intelectuais, para servirem de quadros do Mídia Sem Máscara, através do oferecimento de cursos de filosofia e línguas e grupos de estudos literários (PATSCHIKI, 2012, p. 58).

Patschiki considera o Mídia Sem Máscara um movimento neofascista, que funcionaria como um partido político. Segundo ele, a partir de 2005, após sua demissão de vários jornais e revistas, Carvalho radicaliza sua prática política anterior, "passando a agregar e refinar projetos de cunho chauvinistas e fascistizantes, militando abertamente por partidos e organizações de novo tipo, que não se colocassem somente contra uma possível ascensão da esquerda, mas contra qualquer abertura democratizante permitida pela burguesia” (PATSCHIKI, 2012, p. 69).

O Mídia Sem Máscara seria um partido porque cumpriria uma fun- 
ção partidária, ou seja, organiza e dissemina um discurso ideológico através dos seus intelectuais, forma quadros e militantes de base e arregimenta simpatizantes usando como estratégia principal a guerra de posições, atuando em várias organizações e frentes (incluindo a sua rede extra-partidária), cujo objetivo é atuar em momentos de crise política aberta (PATSCHIKI, 2012, p. 71).

O trabalho de Lucas Patschiki é praticamente o único no campo acadêmico sobre Olavo de Carvalho e o Mídia Sem Máscara. Mas existem análises de outros pensadores expressas em mídias alternativas e também nas dominantes. O cientista político Álvaro Bianchi, por exemplo, afirma que, embora Carvalho não seja um acadêmico, é um intelectual de grande influência na opinião pública brasileira, exercendo atividade intelectual há várias décadas como articulista em jornais de grande circulação e nas redes sociais. Bianchi enfatiza que "há pouca verdade” na narrativa filosófica de Carvalho, porém, ela é persuasiva e eficaz por abordar "os medos e as inseguranças do homem comum perante as transformações do mundo contemporâneo" (COLETTA, 2018).

Bianchi diz ainda que Carvalho "reciclou” para o contexto brasileiro "de modo bastante eficaz" o tema de um suposto marxismo cultural, que faz parte do discurso da direita nos Estados Unidos desde a década de 1970. O autor não tem dúvidas de que as teses apresentadas por Carvalho nessa área são teorias conspiratórias. "Ele [Olavo de Carvalho] atribui um peso ao marxismo nas universidades brasileiras que simplesmente não existe” (COLETTA, 2018, s.p.).

Já Esther Solano chama a atenção para o fato de que Carvalho soube se capitalizar com base no novo formato de comunicação: fácil, rápido, polêmico e combativo. É a forma comunicativa do best seller, daquele palestrante que tem um conteúdo muito simples e mastigado. 
Uma coisa fácil, polêmica e que faz sucesso” (COLETTA, 2018, s.p.).

Segundo o professor de Direito e Relações Internacionais, Fabrício Pontin, a narrativa conspiratória de Carvalho “dá um curto-circuito na tentativa de crítica”, ou seja, se alguém diz que Olavo está errado, tal crítico de seu pensamento passa a fazer parte da conspiração e estaria "trabalhando para manter todos iludidos". Mas o autor considera que Carvalho explora “os delírios da ortodoxia da academia brasileira” que se fecha em grupos que não dialogam com a sociedade, enquanto Carvalho mantém um diálogo aberto com os seguidores, respondendo e-mails, fazendo conferências com seus admiradores, respondendo as ansiedades dos seus seguidores. Nesse sentido, haveria um vazio deixado pela intelectualidade acadêmica, enquanto muitas pessoas não se sentem representadas pelas forças políticas e pelos pensamentos correntes: "O Olavo não é o grande autor da extrema direita brasileira. Ele se tornou o grande intérprete das ansiedades de massa no Brasil, um cara que foi capaz de ler as vulnerabilidades e demandas sociais muito melhor que muito crítico cultural marxista que insiste em achar que Adorno vai nos ajudar a explicar esse ou aquele aspecto do problema de classe” (OUTRAS MÍDIAS, 2019).

A análise de Pontin é elucidativa acerca da estratégia de Carvalho ao se basear em uma suposta erudição filosófica, propagandeando que ele próprio teria uma grande capacidade de interpretação dos trabalhos clássicos da Filosofia Ocidental que o permitiria demonstrar o verdadeiro "sentido" destes textos, escondidos por um complô dos filósofos das universidades. Além disso, Pontin aponta que Carvalho explora as vulnerabilidades do sistema educacional brasileiro e se coloca como um "profeta” de uma suposta "guerra cultural”, aproveitando da incompreensão de parte do público sobre as novas dinâmicas sociais de gênero e de organização política. Ele trabalha também com um senso 
de nostalgia e uma "vontade de desaceleração da pauta progressista”, atraindo muitos insatisfeitos com tais pautas para um movimento de base organizado por ele que explora essas ansiedades sociopolíticas de parte da população, oferecendo uma explicação fácil e direta para as mudanças dos últimos anos (OUTRAS MÍDIAS, 2019).

Miguel aborda o que seria para ele os três eixos da extrema-direita brasileira: o libertarianismo - baseado no ultraliberalismo, prega o menor Estado possível e considera toda situação nascida dos mecanismos de mercado justa por definição; o fundamentalismo religioso - baseado na crença em uma verdade revelada divinamente, anulando qualquer possibilidade de debate; e o anticomunismo - relacionado também com "bolivarianismo". Esses eixos podem aparecer juntos, e ele dá como exemplo o pensamento de Olavo de Carvalho, no qual confluem-se o reacionarismo moral e o anticomunismo exacerbado, produzindo discursos como a crença em um complô para derrubar o capitalismo e a “civilização ocidental” através da dissolução da moral sexual convencional e da estrutura familiar tradicional. Difundindo o que seria o "marxismo cultural" baseado supostamente nas ideias de Gramsci, Carvalho acredita que a estratégia gramsciniana é “apagar da mentalidade popular, e sobretudo do fundo inconsciente do senso comum, toda a herança moral e cultural da humanidade” (MIGUEL, 2019, p. 21).

\section{A análise do discurso islamofóbico em Olavo de Carvalho}

Para abordar a islamofobia em Olavo de Carvalho e no Mídia Sem Máscara, serão analisados dois artigos de autoria do próprio Carvalho e publicados no site do movimento. O primeiro artigo é A Revolução 
Abrangente, também divulgado no Diário do Comércio, em 27 de outubro de 2013; o segundo artigo intitula-se As Garras da Esfinge - Rene Guenon e a Islamização do Ocidente, publicado em Verbum, Ano I, Números 1 e 1, julho-outubro de 2016. A análise iniciará com a abordagem do significado acional dos discursos, para em seguida passarmos para os significados representacional e identificacional, de acordo com a metodologia de Farclough citada anteriormente.

\section{O Significado Acional do Discurso Islamofóbico de Olavo de Carvalho}

Um relatório britânico, Runneymede Report, de novembro de 1997, define islamofobia como "'o medo, ódio e hostilidade direcionado ao Islã e aos muçulmanos perpetrados por uma série de visões fechadas que insinuam e atribuem estereótipos e crenças negativos e depreciativos aos muçulmanos” (apud RAMOS, 2015, p. 108). Há autores que relacionam islamofobia com racismo, sendo um deles, Ibrahim Kalin, classificando-a como uma espécie de racismo cultural, enfatizando que "é impossível separar a Islamofobia do ódio étnico contra árabes, asiáticos e negros.” (KALIN, 2011, p. 600)

Assim sendo, podemos definir a postura de Carvalho como racista e que visa difundir uma imagem estereotipada e preconceituosa acerca do islã em geral, e dos muçulmanos, contribuindo para gerar atitudes de intolerância contra eles.

De acordo com a metodologia de análise de discurso de Farclough, iniciaremos com o significado acional do texto. Ao perceber os textos como uma forma de ação política que visa influenciar a opinião e visão de mundo dos leitores, sendo, portanto, uma forma de interação social, eles têm uma função relacional. 
É importante então discutir o conceito gramsciniano de hegemonia, que trouxe grandes contribuições para o estudo da dominação de classe nas sociedades capitalistas mais desenvolvidas. Segundo Portelli (1977, p. 65), Gramsci enfatizava, além da coerção, o consentimento das massas através do convencimento e da persuasão, sendo para ele muito relevante a direção cultural e ideológica da classe dominante sobre toda a sociedade, retirando o conceito de hegemonia de seu caráter puramente político baseado na formulação leninista.

Para Gramsci, o terreno essencial da luta está na sociedade civil, pois o grupo que a controla torna-se hegemônico, coroando tal hegemonia na conquista da sociedade política, estendendo-a ao conjunto do Estado, formado pela sociedade civil mais sociedade política (PORTELLI, 1977). A luta pela hegemonia é denominada por Gramsci de “guerra de posição”, ou seja, conquista de “posições e de espaços, da direção político-ideológica e do consenso dos setores majoritários da população, como condição para o acesso ao poder de Estado e para a sua posterior conservação” (COUTINHO, 1992, p. 89).

Para Gramsci, então, “a hegemonia é um contínuo processo de formação e suplantação de um equilíbrio instável” (GRAMSCI, 1988, p. 423), sendo o discurso um meio de se lutar pelo consenso. Assim, as práticas discursivas realizadas através das práticas textuais são formas de estabelecer a hegemonia, e estão ligadas a determinadas práticas sociais que contribuem para a manutenção de relações assimétricas de poder sustentadas em redes de práticas.

Assim sendo, no âmbito da sociedade civil, estão partidos políticos, imprensa, instituições sociais, etc, sendo atualmente as redes sociais um espaço da sociedade civil muito utilizado para a disseminação de determinadas ideias, valores, concepções de mundo ligados a determinados grupos sociais, visando convencer a sociedade e atrair 
adeptos que possam colaborar com suas práticas sociais. No caso aqui abordado, o MSM e seu líder Olavo de Carvalho procuram conquistar a hegemonia por meio da persuasão e dos discursos de cunho políticoideológico, mas apresentados como se fossem verdade. Por isso, a importância de analisar a prática textual desse grupo e, começando pelo significado acional, serão abordados o gênero e o grau de intertextualidade.

O primeiro artigo, A Revolução Abrangente, tem como tese central a ideia de união de um amplo conjunto de movimentos e pautas sociais associados ao "esquerdismo", como o islamismo, o indigenismo, o estatismo, a negritude, a liberação das drogas, o homossexualismo, o feminismo, apresentados sempre de forma pejorativa e em oposição aos valores do ocidente cristão.

No que diz respeito ao gênero, podemos afirmar que o texto é um artigo político, que procura convencer os leitores dos seus argumentos e persuadi-los a agir em conformidade com a visão de mundo passada no texto. Assim, Carvalho busca desenvolver nos leitores a ação política contrária aos elementos apresentados no texto como os inimigos a serem combatidos e reforçar ou gerar preconceitos e conservadorismos de caráter político, social e moral religioso, com o objetivo de manter a ordem social dominante. O pré-gênero do texto é, portanto, o argumentativo-dissertativo.

Carvalho fala de um suposto movimento revolucionário, unido por forças heterogêneas, mas com um objetivo em comum, e que estariam “unidas tão somente pelo ódio comum a um inimigo que permanece também vago e indefinido o bastante para deixar à liderança revolucionária o espaço livre para toda sorte de arranjos e acomodações oportunistas” (CARVALHO, 2013). Afirma-se, portanto, que não há princípios ideológicos positivos no movimento revolucionário, enfa- 
tizando seu pragmatismo para derrotar um inimigo comum a todos os componentes do movimento, levando o leitor a concluir que a "ideologia” dos movimentos revolucionários é o ódio e o desejo de poder ilimitado. Os argumentos são: não existe mérito nos movimentos revolucionários, sua essência é negativa e são forças autodestrutivas e incapazes de construir. É apresentada, então, uma visão pejorativa de todo movimento revolucionário.

Carvalho associa ao Islã todos os atributos negativos e pejorativos apresentados em relação aos movimentos revolucionários em geral. Para ele, o Islã seria "por essência um projeto de sociedade, um código civil completo que regula todas as relações humanas” (CARVALHO, 2013), possuindo um caráter autoritário que “aceita conviver com outras formas de sociedade enquanto não se sente forte o bastante para islamizá-las de alto a baixo e banir do espaço público - e até mesmo da vida privada - tudo o que não seja expressamente determinado pelo Corão” (CARVALHO, 2013). Assim, Carvalho atribui ao islã e a todo movimento revolucionário um sentido de dominação total, utilizando, inclusive, o conceito de "totalitarismo".

O uso de tal conceito para se referir ao islã não é acompanhado, contudo, de uma definição conceitual sobre o mesmo. Apenas é utilizado com fins políticos no interior do discurso para desqualificar a civilização islâmica como um todo. Carvalho parte de definições dicotômicas e generalizantes de cunho liberal para construir opostos binários baseados em concepções de "bem” e “mal”. Nesse sentido, cabe a crítica de Chasin (2013) às definições liberais sobre o conceito de totalitarismo, referindo-se principalmente à definição de Neumann (1969, p. 270), que distingue o estado totalitário como aquele que destrói a linha entre o estado e a sociedade, havendo uma politização total da sociedade por meio do partido único. Chasin afirma que as defi- 
nições liberais de totalitarismo se baseiam em negações relativas aos caracteres liberais. Tal concepção dicotômica parte de alguns pressupostos: "abstrata relação excludente entre poder material e poder jurídico; e a atribuição também em abstrato de valor positivo ao campo jurídico e de negativo ao poder material. Pressupostos que implicam considerar o estado liberal uma sorte de fim da história, portanto, racionalmente insuperável, eterno como valor prático e teórico” (CHASIN, 2013, p. 15).

Segundo Carvalho, o islã e o movimento revolucionário aliaramse "tão logo a luta de classes e a luta de raças, nas primeiras décadas do século 20, com o comunismo e o nazismo, respectivamente, assumiram a feição explícita de uma guerra de culturas e de nações pelo domínio do globo terrestre" (CARVALHO, 2013). Neste trecho, o autor coloca no mesmo patamar islamismo, comunismo e nazismo como representantes do "mal”, desconsiderando totalmente as especificidades de cada um e os projetos sociais diferenciados. Observa-se uma operação discursiva que visa representar também o nazismo como pertencente a esse dito "movimento revolucionário”, o que é conceitualmente falando uma distorção da essência de um regime que foi essencialmente conservador. ${ }^{10}$ Aparece também no discurso a concepção de uma guerra cultural entre civilizações do "bem” e do "mal”.

A representação que é feita acerca do islã é contraposta à representação do cristianismo. De acordo com Carvalho, embora o cristianismo sempre tenha lutado pela expansão mundial, esta seria apenas baseada em "uma mensagem de salvação que se dirigia às almas individuais” (CARVALHO, 2013), dando ao cristianismo um viés altamente conservador em termos sociais e políticos, com ausência de

\footnotetext{
${ }^{10}$ Nesta discussão, insere-se também a tese de Carvalho de que o nazismo seria um regime de esquerda, em uma tentativa "revisionista” de alocar as atrocidades nazistas no campo dos seus adversários políticos.
} 
qualquer intenção transformadora da realidade social, e dotado de capacidade de adaptação. Por isso, não sendo revolucionário, o cristianismo seria necessariamente "bom” em oposição a um islã revolucionário. No entanto, esta concepção conservadora da prática cristã é fruto da opção política do autor, pois existem vertentes cristãs que advogam a capacidade dos princípios cristãos impactarem toda a estrutura social e que também resultam de opções políticas, neste caso, à esquerda, sendo um exemplo a teologia da libertação.

É importante abordar a questão da intertextualidade neste texto, ou seja, verificar se existe diálogo com outros discursos, textos e percepções. No artigo aqui analisado, verificamos que não há tal diálogo, não havendo referências diretas nem indiretas a autores ou outros atores sociais e políticos que abordem os temas centrais do texto: islamização da Europa, disseminação do homossexualismo, abortismo, ecologismo, feminismo etc. O autor não utiliza argumentos externos nem para confrontar a sua narrativa nem para referendá-la. Ele sustentase somente em pressuposições acerca de tais elementos, que surgem como "dados da realidade” que são apresentados aos interlocutores, ajudando a reforçar, no leitor, a percepção de que o que o texto diz é uma "verdade" incontestável.

Os não-ditos e os silêncios presentes no texto também são uma forma de discurso, servindo para dar aos seus argumentos uma aparência de legitimidade. Carvalho esconde os reais propósitos dos elementos ditos como "revolucionários”, suas pautas e a justeza das mesmas, os condicionantes sociais e políticos que levaram ao surgimento de tais pautas e a importância delas para a luta contra situações de opressão, transformando movimentos que possuem causas humanamente compreensíveis e justas em "inimigos terríveis” e no "mal absoluto”.

$\mathrm{O}$ autor omite as causas sociais e econômicas que levam milha- 
res de pessoas de religião muçulmana a imigrarem de seus países de origem para a Europa, causas estas muitas vezes provocadas pelos próprios países europeus em sua expansão imperialista pelas periferias do mundo, ocasionando guerras e instigando conflitos locais. Assim, o grande número de muçulmanos na Europa pode ser interpretado como ocasionado por "conspirações islâmicas”, e não resultado de processos históricos de caráter econômico e social. Transforma-se as populações muçulmanas, as quais muitas vezes vivem em situação precária e marginalizadas nos países europeus, em algozes da civilização judaico-cristã.

Quanto à associação de esquerdismo com islamismo, só parece lógico ao se omitirem informações de caráter histórico que mostram não haver tal associação, como a oposição dos talibãs ao governo comunista do Afeganistão e, por outro lado, o apoio dos EUA (um país de cultura cristã) às forças muçulmanas fundamentalistas contra o governo apoiado pelos soviéticos (VIZENTINI, 2002) e as relações geopolíticas e comerciais entre os EUA e países de regime islâmico fundamentalista, como a Arábia Saudita (LITTLE, 2004).

Ao analisarmos este primeiro artigo, podemos perceber influências do pensamento neoconservador norte-americano no discurso islamofóbico de Carvalho e do MSM. O neoconservadorismo possui interligações ideológicas com a extrema-direita próxima ao fascismo, por buscar uma sociedade harmoniosa, homogênea (étnica e cultural) e sem conflitos de classe, além de defender o resgate da sociedade tradicional (que acredita ser verdadeira), baseado nos princípios de família, da religião e do desenvolvimento da nação acima dos objetivos individuais (MILZA, 1992).

Uma das principais características do neoconservadorismo ${ }^{11}$ é a

${ }^{11}$ Os neoconservadores podem ser caracterizados como políticos, funcionários de 
tendência a ver o mundo prioritariamente pela ótica do bem/mal. Por isso, pretendem influenciar a organização e a conformação da ordem internacional de acordo com os valores norte-americanos de forma a tornar o mundo mais seguro para os EUA. Por trás está a ideia de que os princípios norte-americanos são superiores e, por isso, o poderio norte-americano deveria ser usado para fins morais, tendo os EUA responsabilidades especiais no mundo, pois sua sociedade deveria ser modelo para os demais países devido ao seu excepcionalismo. (FUKUYAMA, 2006, p. 2) Segundo Magalhães, “após os ataques terroristas de 11 de setembro de 2001, os neoconservadores ganharam força e se tornaram o grupo mais influente em Washington" (MAGALHÃES, 2008, p. 17).

Segundo Finguerut (2008, p. 16), os neoconservadores fazem uma crítica à inércia do poder americano pós-Guerra Fria e, a partir deste diagnóstico, criam um plano de ação buscando remodelar a política internacional. Eles olham para o mundo e pensam na ocidentalidade judaico-cristã diante de ameaças que, mesmo globais, atingem o conceito de Ocidente como um todo. Essa é a razão de os neoconservadores travarem um diálogo com os autores que pensam na centralidade da cultura na política internacional. ${ }^{12}$

Finguerut (2008, p. 19) aponta ainda que a supremacia militar americana criou, no plano doméstico, uma nova identidade nacional, caracterizada por um destino messiânico, mediante o poder de transfor-

carreira da Casa Branca e intelectuais dos círculos dos Think Tanks de Washington D.C. que revolucionaram a Direita Americana quando repensaram os rumos da política externa dos EUA pós-Guerra Fria e reintroduziram na opinião pública, temas como patriotismo, valorização do poder americano e a viabilidade da unipolaridade no Sistema Internacional (FINGUERUT, 2008, p. 15).

${ }^{12}$ Este diálogo ocorre nos Campi com professores da escola realista como Samuel Huntington e a Nova Geração da Nova Direita, herdeira dos críticos do liberalismo, como por exemplo, Francis Fukuyama e William Kristol (FINGUERUT, 2008, p. 16). 
mação e de pacificação das forças estadunidenses. O pensamento neoconservador define-se como o detentor da solução para os problemas da política externa dos EUA, inovando ao transferir o foco da diplomacia para a segurança. Após os ataques de 11/09/2001, o foco na segurança se reforçou ainda mais, contribuindo para fortalecer a posição dos neoconservadores no governo norte-americano.

Já de antemão, podemos identificar alguns elementos em comum entre Olavo de Carvalho e os neoconservadores neste primeiro artigo analisado: divisão do mundo entre forças do bem e forças do mal, sendo os valores cristãos ocidentais o bem e o islamismo em associação com "movimentos revolucionários" o mal; concepção de uma "guerra cultural” entre nações e civilizações; e construção de inimigos da civilização ocidental judaico-cristã. Mais à frente desenvolveremos melhor esta questão.

No segundo artigo, As Garras da Esfinge - Rene Guenon e a Islamização do Ocidente, Carvalho apresenta a mesma tese central da ameaça do islã ao ocidente através de um projeto de islamização das sociedades ocidentais, usando como fonte a obra de Rene Guenon, Oriente e Ocidente, publicada em 1924. Para desenvolver sua tese, o autor realiza um debate filosófico, no qual ele se contrapõe à corrente tradicionalista e perenialista, cujas ideias centrais são apresentadas ao leitor e depois desconstruídas.

O significado acional do texto é percebido no gênero utilizado pelo autor, que, assim como o artigo analisado anteriormente, é um artigo político, cujo pré-gênero também é argumentativo-dissertativo.

Mas, no que diz respeito à intertextualidade, existe uma diferença em relação ao artigo anterior. Desta vez, há um nível de dialogicidade razoável, pois Carvalho dialoga o tempo todo com autores da corrente tradicionalista e perenialista, citando trechos de suas obras, 
corroborando algumas de suas ideias e desconstruindo outras.

O diálogo é feito, inicialmente, com a obra de Lee Penn, False Dawn: The United Religions Initiative, Globalism, and the Quest for a One-World Religion e com a resenha de tal obra, feita por Charles Upton (autor de The System of the Antichrist). A ideia central é de que há um projeto de formação de uma religião única para dominar o mundo e a noção do “Anticristo” e da religião mundial estão no cerne da islamofobia que Carvalho apresenta neste artigo. Assim, percebe-se que este diálogo é essencial para reforçar a tese islamofóbica central, e a referência a esta obra e ao seu autor serve para dar uma aparência acadêmica ao seu texto.

Lee Penn é o autor com o qual Carvalho tem grande concordância, pois sua visão se opõe à chamada escola perenialista, contra a qual Carvalho também se posiciona, e que tem entre seus autores F. Schuon e R. Guenon, com os quais Carvalho também dialoga. Percebemos, então, que existe um certo nível de tensão no texto, visões e reflexões de caráter filosófico são confrontadas, e tal confronto é estratégico no desenvolvimento da tese do conspiracionismo islâmico defendida por Carvalho.

No nível da linguagem propriamente dita e do significado acional do texto, o autor constrói um discurso da ameaça ao ocidente cristão, levando o leitor a perceber que algo de "ruim” paira no ar e sugere a ocorrência de transformações históricas e espirituais que estariam ameaçando o futuro da humanidade, mas não seriam percebidas pelas pessoas comuns por estarem muito distantes da mídia e dos debates públicos (CARVALHO, 2016).

Carvalho prossegue com o tema da religião mundial, baseandose no livro de Lee Penn que, segundo ele, “descreve e documenta com abundância de fontes primárias a formação e desenvolvimento 
de uma religião biônica mundial, com todas as características de uma paródia satânica” (CARVALHO, 2016). Tal projeto teria o apoio “da ONU, do governo americano, de praticamente toda a grande mídia ocidental e de um punhado de mega fortunas” (CARVALHO, 2016), e teria começado em 1995, com o nome de United Religions Initiative (URI, v. www.uri.org), sendo um "empreendimento, sustentado por recursos financeiros incalculavelmente vastos e apoiado por todo um cast de estrelas do show business e da política, conquistou até o apoio informal do Papa Francisco” (CARVALHO, 2016).

Carvalho aceita o pressuposto de Lee Penn como verdade absoluta, apresentando a tese do autor como praticamente incontestável e isentando o seu trabalho de qualquer processo de interpretação das fontes usadas; além disso, nada diz de como o autor trabalhou as fontes, passando ao leitor a ideia de que seria um trabalho neutro e de que as fontes primárias por si só revelam a realidade.

O United Religions Initiative (URI), apresentado como "prova” do projeto de construção de uma religião mundial, é um movimento que, na realidade, possui um caráter inter-religioso, e não ecumênico, pois não visa a fusão das diversas religiões em uma única, mas apenas a colaboração de religiões diversas em prol de um objetivo comum, mantendo cada uma a sua especificidade. Carvalho, no entanto, tenta desqualificar o movimento, relacionando-o com um objetivo maligno de dominação mundial, que ameaçaria o ocidente e o Brasil, baseado na ideia de "universalismo”, que sustenta o “dogma” da "equivalência de todas as religiões em dignidade e valor” (CARVALHO, 2016), discurso que seria defendido "por toda a grande mídia mundial, pelos parlamentos, pelas legislações da quase totalidade dos países e pela maioria das próprias autoridades religiosas” (CARVALHO, 2016).

O autor critica, então, a visão de que todas as religiões têm o 
mesmo valor e dignidade, empregando o termo dogma para se referir a essa ideia com o claro objetivo de desqualificá-la para o leitor, pois dá o sentido de que é algo imposto e não passível de contestação. Carvalho parte do pressuposto de que há uma hierarquia entre as crenças, umas seriam melhores do que as outras ou mais verdadeiras do que as outras.

Carvalho inicia sua crítica à corrente ghenoniana-schuoniana ao discordar de sua concepção de distinção “vertical” ou hierárquica entre as partes “superiores” (ou esotéricas) e “inferiores” (ou exotéricas) de todas as religiões. Embora concorde que as religiões possam levar a uma mesma Verdade Primordial, não aceita a visão de que o acesso a essa verdade só seja possível nas partes “superiores” ou esotéricas das crenças. Ele nega que tal hierarquia exista nas demais religiões, inclusive, no cristianismo, concordando nesse ponto com Schuon.

Como Guenon insiste na existência de tal hierarquia por querer aplicá-la a todas as crenças, Carvalho insinua que Guenon possui intenções não declaradas. "Qual a razão pela qual Guénon teria escolhido enquadrar à força todas as tradições numa dupla de conceitos que não se aplicava apropriadamente a nenhuma delas exceto o islamismo em particular?” (CARVALHO, 2016).

Ao desenvolver o tema da metafísica no texto, definindo-a como uma "estrutura da realidade universal”, que se manifesta nos diversos níveis ou planos da existência, Carvalho afirma que, embora todas as crenças permitam o acesso ao mundo metafísico, o conhecimento desse mundo não é perfeito em todas elas; umas seriam mais perfeitas do que as outras em termos de conhecimento da realidade metafísica. Atingir o chamado Princípio absoluto não seria o que torna uma crença perfeita, e sim o conhecimento que se obtém dele, expresso no retorno perfeito da essência de tal Princípio para o homem e a socie- 
dade (CARVALHO, 2016).

Em seguida, Carvalho inicia a problematização da concepção tradicionalista de Guenon, segundo a qual todas as organizações iniciáticas cristãs teriam desaparecido após a Idade Média, vendo "na perda da dimensão iniciática a raiz de todos os males do mundo moderno" (CARVALHO, 2016). Essa discussão é apresentada como um fio condutor para a tese central de todo o artigo: a ameaça sobre o ocidente por um projeto de islamização. Todo o restante do texto é dedicado a induzir o leitor a perceber tal projeto, tendo como pano de fundo a tradição perenialista, o islã e a obra de Guenon.

O discurso apresenta o ocidente cristão como a vítima de uma conspiração. Ao apontar para as sugestões que o perenialismo oferecia ao católico, a partir dos anos 1960, Carvalho afirma que todas elas visavam a destruição do ocidente cristão. A primeira sugestão seria a conversão pura e simples ao islã; a segunda seria se abrigar na Igreja Ortodoxa Russa onde ainda haveria resíduos de esoterismo; a terceira seria a filiação a uma tariqa ${ }^{13}$ multi confessional, onde se poderia praticar ritos iniciáticos islâmicos sem conversão formal ao islã (CARVALHO, 2016).

Ao abordar a tese de Guenon, Carvalho mostra o que seria, para o autor, possíveis desenvolvimentos: a queda na barbárie; a restauração da tradição católica sob a orientação de mestres espirituais islâmicos; e a islamização total, ou por meio da infiltração e propaganda ou através da ocupação militar. Deduz então, que o autor defendia a sujeição do ocidente ao islã (CARVALHO, 2016).

Ao associar o islamismo com o fascismo, afirmando que "importantes autoridades religiosas islâmicas deram apoio total ao Führer,

\footnotetext{
${ }^{13}$ As taricas são organizações compostas pelos praticantes da mística islâmica havendo também exemplos de muitas taricas ecumênicas.
} 
especialmente na questão do extermínio dos judeus” (CARVALHO, 2016), Carvalho adota a estratégia discursiva de usar alguns exemplos particulares para culpabilizar todo o islã e seus adeptos pelo extermínio dos judeus pelo nazismo alemão. Observamos, contudo, que esta estratégia está cheia de omissões. Nenhuma palavra é dita do apoio ostensivo de setores institucionais do cristianismo ocidental ao fascismo e ao nazismo, da criação do Estado do Vaticano como resultado do acordo entre o fascismo italiano, sob direção de Mussolini, e a Igreja Católica de Roma, das indenizações recebidas pelo Vaticano devido à perda de terras durante o processo de unificação italiana, do apoio de igrejas protestantes e da Igreja Católica ao nazismo alemão, tendo como motivo principal o combate ao comunismo (KERTZER, 2017). Assim sendo, se o raciocínio de Carvalho estivesse correto em relação ao islã, ele deveria ser estendido também ao próprio cristianismo ocidental. Mas como o objetivo do autor é criar um estereótipo sobre a civilização islâmica com base em condutas individuais ou de alguns setores islâmicos, ele omite que setores cristãos também apoiaram o fascismo, o que não nos autoriza a dizer que todo o ocidente cristão ou todos os cristãos foram fascistas.

A outra estratégia discursiva de Carvalho é associar intimamente islamismo e comunismo, estabelecendo junto ao leitor um sentimento de aversão aos dois grupos transformados em inimigos e ameaçadores da integridade do ocidente cristão. Ele fala de uma "colaboração íntima entre governos islâmicos e regimes comunistas no esforço antiocidental conjunto” (CARVALHO, 2016), do apoio da esquerda mundial à "ocupação muçulmana do Ocidente pela imigração em massa” (CARVALHO, 2016) e de um suposto boicote ao "combate ao terrorismo islâmico" (CARVALHO, 2016).

Neste trecho, há algumas inferências do autor, suposições passa- 
das como se fossem verdade: haveria uma conspiração islâmica para dominar o ocidente, a imigração em massa dos muçulmanos para o ocidente seria parte de tal conspiração, quem defende os imigrantes compactua com tal projeto. Assim sendo, o fato de grupos à esquerda do espectro político tenderem a se contrapor à xenofobia contra imigrantes, incluindo os de fé islâmica, baseados na ideia de tolerância e inclusão social, é interpretado por adeptos de teorias conspiratórias como prova de seus pressupostos, embora não haja racionalmente ligação alguma entre uma coisa e outra. Tudo está no âmbito do discurso baseado numa visão binária de mundo em que o ocidente cristão é a vítima de um oriente islâmico ameaçador, relacionando atos ou ideias que não possuem ligação entre si, para envolvê-las numa teia conspirativa.

O suposto envolvimento de Guenon na conspiração aparece na seguinte frase: “A islamização do Ocidente - discreta ou ostensiva, pacífica ou violenta - é o objetivo central e, na verdade, único, de toda a obra de René Guénon” (CARVALHO, 2016), pressupondo que as ideias defendidas por Guenon possuem um objetivo político-religioso e estariam a serviço do projeto conspiracionista de dominação do ocidente cristão pelo islamismo. Assim, a interpretação que Carvalho dá ao que seriam as supostas motivações de um autor é passada ao leitor como não passível de questionamento, já que ele estaria usando como “prova” os próprios escritos de Guenon.

A islamofobia presente no discurso de Carvalho reflete o fenômeno nos EUA, sendo importante enfatizar que o autor reside no país norte-americano, reverberando em grande parte as paranoias e os medos desenvolvidos após os ataques de 11 de setembro às torres gêmeas do World Trade Center.

A autora Cinthia Weber (2010) nos ajuda a refletir sobre o fenô- 
meno da islamofobia. Ela parte de uma metáfora (presente no discurso de Carvalho, inclusive), que vê a cultura islâmica como uma "besta" a ser combatida, construindo-se o sentimento do medo generalizado, o qual produz resultados coletivos. Tal discurso tem sido muito utilizado nos EUA após os atentados de 11 de setembro de 2001.

Já o antropólogo Paulo Pinto relaciona a islamofobia com os discursos orientalistas, que constroem um imaginário cultural acerca do islã como uma alteridade radical, dotando-o de qualidades negativas - irracionalidade, fanatismo, autoritarismo, opressão às mulheres, violência e tradicionalismo - em contraste às que definiriam o "mundo ocidental”- razão, tolerância, liberdade, igualdade e modernidade (PINTO, 2010, p. 21-22).

Segundo Ramos, o orientalismo euro-americano e a islamofobia contemporânea baseiam-se em construções e imagens do Oriente islâmico sempre opostos aos padrões de vida pretendidos pelos ocidentais. "Para além disso, ambos insistem na assimetria entre as culturas, apostando na supremacia inconteste do Ocidente sobre o Oriente”bárbaro"” (RAMOS, 2015, p. 79).

Sendo assim, o conceito de orientalismo, de E. Said, também é bastante útil para a compreensão das teses islamofóbicas contemporâneas. Segundo Said, o “orientalismo” é uma invenção ocidental, um complexo de representações culturais que o ocidente produziu sobre o oriente e que legitimava as relações de poder entre o ocidente colonizador e o oriente colonizado. Orientalismo seria então um "estilo de pensamento baseado numa distinção ontológica e epistemológica feita entre o ‘Oriente' e o ‘Ocidente' ” (SAID, 2007). 


\section{Os Significados representacional e identificacional do Discurso Islamofóbico de Olavo de Carvalho}

Ao entrarmos no campo das representações, o trabalho de Sunaina Maira (apud CARVALHO, 2015, p. 116) revela um amplo processo histórico de representação do “Outro” islâmico, fazendo-se referências a acontecimentos como a Inquisição Europeia e as Cruzadas, e vendo-se uma incompatibilidade entre os valores do islã e os valores do Ocidente. Posteriormente, tais representações europeias penetraram no território norte-americano ainda durante o processo de colonização, criando narrativas e imagens sobre o Islã que atualmente são relembradas e ressignificadas. De uma certa forma, esta influência aparece no discurso de Carvalho, principalmente quando ele tenta opor cristianismo a islamismo.

O nível representacional do texto é exatamente onde o discurso opera, através dele podemos observar as representações que o autor faz da realidade e de alguns elementos desta realidade. Neste âmbito, está a função ideacional, baseada em pressupostos ideológicos do autor, bem como as inferências que baseiam todo o texto.

O conceito de ideologia é então fundamental. Para a análise aqui realizada, adotaremos a concepção crítica de Thompson (2002), para quem a ideologia é, por natureza, hegemônica, pois serve para estabelecer e sustentar relações de dominação e para reproduzir a ordem social que favorece determinados grupos dominantes. A concepção de ideologia de Thompson pode, inclusive, ser articulado com o trabalho de Norman Fairclough (2001), que aborda a relação dialética entre estrutura social e discurso, enfatizando que o discurso é moldado pela estrutura social, mas é também socialmente constitutivo. Este 
mesmo raciocínio pode ser aplicado à ideologia que, embora esteja relacionada a uma dada estrutura social, é também constitutiva dessa estrutura.

Podemos ver então os pressupostos ideológicos de Carvalho ao produzir os textos aqui analisados. No que diz respeito ao primeiro artigo, A Revolução Abrangente, podemos enumerar alguns desses pressupostos. São eles: movimentos revolucionários são ruins; existiria uma intenção de disseminar o homossexualismo e islamizar as massas; toda liderança revolucionária é afeita a arranjos e oportunismos; os movimentos revolucionários são hipócritas porque se apoiam em forças sistêmicas e estão associados ao ódio.

Na construção da representação negativa que o autor faz dos movimentos revolucionários, uma figura de linguagem é utilizada: a metáfora. Carvalho (2013) compara o “movimento revolucionário” a um "monstro de mil faces e inumeráveis tentáculos”, ou seja, os movimentos sociais e suas pautas diversas (todas elas condenadas como sendo o "mal”) estariam associados a um projeto conspiracionista para envolver (daí a ideia dos inumeráveis tentáculos) toda a sociedade e o ocidente cristão.

A representação do mundo é binária, simplificando-se seus elementos em lados opostos e excludentes, o "bem” e o “mal”. O islã seria totalmente ruim, pois é naturalmente revolucionário, já que pretenderia moldar toda a humanidade futura à sua interpretação abrangente da história universal; o cristianismo, por sua vez, seria algo bom porque se opõe a essa pretensão de construir uma nova sociedade, sendo sua única intenção a salvação das almas. O autor mostra uma representação ideológica do cristianismo, ao defini-lo monoliticamente como sendo essencialmente conservador social e politicamente, desconsiderando que existem diversas formas de apreender a mensagem de 
Cristo e vivenciá-la nas interações sociais, assim como no islamismo.

O autor parte, portanto, de um pressuposto político conservador: o de que o dever de todo cristão é se adaptar à realidade e nunca tentar transformá-la, pois transformações da realidade são ruins, o bom seria a manutenção das estruturas sociais, não importando a quem elas servem; o Islã seria naturalmente autoritário, pois teria um caráter revolucionário - e o autor associa revolução a autoritarismo - e expansionista, daí a ideia de que haveria um projeto de islamização de toda a sociedade.

Se o movimento revolucionário é ruim, as resistências a ele seriam automaticamente boas e positivas, e Carvalho cita os valores religiosos (neste caso, os valores judaico-cristãos), os sentimentos patrióticos e os interesses econômicos de grupos e facções (leia-se os interesses das classes dominantes).

As omissões e os não-ditos do texto citados anteriormente possibilitam que o discurso de oposição entre Islã e ocidente judaico-cristão em termos do "mal” contra o "bem” pareça crível, quando, na verdade, é uma representação ideológica e simplificadora da realidade com base numa visão dualista.

Esta visão binária de mundo tem uma importância fundamental na produção do significado identificacional do texto, pois a construção de inimigos a serem combatidos fortalece a identidade política e moral religiosa de um ocidente cristão em oposição a um islamismo que vem do oriente. O “nós” contra “eles” é construído com base na valoração positiva dos elementos que comporiam a identidade do "nós" e na valoração negativa do “eles”, desqualificados sempre como algo ruim.

Neste primeiro artigo, como o autor não está combatendo somente o islã, mas todos os movimentos sociais que lutam contra as estruturas sociais, econômicas, políticas e culturais opressoras, podemos 
concluir que o objetivo de Carvalho é deslegitimar todos esses movimentos através de uma representação pejorativa da ideia de revolução e transformação, sempre associada com destruição, oportunismos, ódio e inconsequências, em nome de uma ideologia conservadora que pretende manter o status quo dominante. Os adversários políticos são transformados em inimigos que supostamente ameaçariam os valores da civilização cristã e uma suposta essência conservadora do cristianismo.

No segundo artigo, As Garras da Esfinge - Rene Guenon e a Islamização do Ocidente, o autor parte de um pressuposto ideológico, que também aparece no primeiro artigo, mas de forma mais sutil, o de que o islã pretende islamizar o ocidente. No primeiro artigo, há uma ênfase nas supostas relações entre o islamismo e os movimentos revolucionárioss sendo seu objetivo primordial desqualificar não somente o islã, mas também todos os movimentos e pautas sociais que confrontam com a visão de mundo conservadora de Carvalho, tanto do ponto de vista social e econômico, como moral.

Já em As Garras da Esfinge, o tema do islã é central, e o objetivo principal do texto é convencer o leitor de que o islamismo possui um plano de dominação mundial, havendo uma exploração acentuada da tese conspiracionista da dominação islâmica. Carvalho sustenta seu pressuposto com base em uma obra escrita em 1924 por um autor Rene Guenon - cujas ideias filosóficas e espirituais só poderiam ter esse objetivo e não outro. Nesse caminho interpretativo, Carvalho passa a fazer referências a momentos da biografia de Guenon, dandolhes significados totalmente ligados à sua tese central. Fala, por exemplo, de sua partida para o Egito, em 1930, colocando-a numa etapa de entrega total da situação a autoridades islâmicas, vendo-as como controladoras de todas as ações de Guenon quando estava no ocidente. A 
etapa seguinte seria a tática do terrorismo e da imigração em massa de muçulmanos ao ocidente (CARVALHO, 2016). É clara então a tese de que a imigração muçulmana está ligada à intenção de islamizar o ocidente.

Porém, o terrorismo e a imigração possuem explicações variadas, indo desde questões sociais e econômicas, a motivações de ordem política e de luta anti-imperialista de setores do islamismo, que não representam o islã como um todo. A crença na imigração em massa de muçulmanos como um projeto conspiracionista - abstraindo-se as circunstâncias sociais, econômicas e políticas dessa imigração - é uma opção de viés claramente ideológico que baseia todo o pressuposto presente na tese central. Esta tese não é resultado de uma pesquisa científica.

O pressuposto ideológico orienta toda a dedução e conclusão que se faz de dados da realidade, ligando-se terrorismo e imigração, através da abstração de outros componentes dessa mesma realidade que poderiam confrontar a representação binária do bem contra o mal, ou seja, a responsabilidade do próprio ocidente no fomento de situações de guerra que levam à prática terrorista e à necessidade de imigrar por parte de povos inteiros sujeitos à exploração econômica e social pelo ocidente.

O artigo é concluído fazendo-se alusão ao seu título: em As garras da Esfinge - René Guénon e a islamização do Ocidente Carvalho (2016) pressupõe que o pseudônimo “Esfinge” de Guenon está relacionado com a existência de um enigma em sua obra que, ao ser decifrado, permitiria que a vítima pudesse se defender e lutar contra o projeto de dominação islâmica do qual a obra de Guenon seria uma prova cabal. Esta conclusão leva o leitor a realizar as conexões de todas as partes do artigo e compreender o mundo da forma binária in- 
duzida por Carvalho, passando a compartilhar das representações que este faz do islã, do muçulmano, da esquerda e do ocidente cristão.

As partes do artigo estão estritamente conectadas para produzir uma representação islamofóbica da realidade, e desnuda-se a função de toda a discussão filosófica realizada no texto e porque determinados temas aparecem em meio a tal discussão. Por que Carvalho discute com as teses perenialistas tradicionalistas? Porque a filosofia perenialista guenoniana seria a prova de uma suposta conspiração islâmica contra o ocidente. Por que a discussão sobre o ecumenismo? Para apresentar ao leitor a ideia de uma suposta ameaça ao mundo ocidental cristão baseado no domínio de uma religião mundial, tese do anticristo, que no início do texto não está claramente associado ao islã, mas tal associação vai se desvelando no decorrer do texto. Nesta parte, é digno de nota o uso proposital do autor do conceito de ecumenismo para se referir a um projeto inter-religioso, ofuscando a diferença entre proposta ecumênica e proposta inter-religiosa. Adotar o conceito de ecumenismo para um movimento que é inter-religioso visa a tornar aceitável o pressuposto de que por trás de tal movimento existiria um projeto de criação de uma religião mundial.

Por que a discussão sobre a metafísica? Para sustentar a tese de que não existe equivalência em termos de legitimidade e valor entre todas as religiões, e sim uma hierarquia entre elas, com o pressuposto da superioridade do cristianismo. A ideia de que as religiões não exprimem com a mesma perfeição a Verdade Primordial e o retorno das mesmas não é igual em termos de qualidade significa que as religiões que não produzem um conhecimento verdadeiro sobre o mundo metafísico não produzem bons resultados para o homem e a sociedade. Como o islã é apresentado como o algoz do ocidente cristão, pressupõe-se que o autor quer dizer que o islã não exprime com 
perfeição a realidade primordial, deduzindo-se daí o terrorismo (já que o islamismo é associado sempre a práticas terroristas) e a vontade de domínio sobre o ocidente cristão, assim como a ideia de que o ocidente é civilizado e seus valores superiores porque o cristianismo seria a expressão perfeita de Deus. Cristo versus anticristo; ocidente versus oriente islâmico.

A religião mundial fica então associada com o islã, havendo estreita conexão entre a temática que inicia o artigo - globalismo, universalismo e criação de uma religião única - e a sua temática final a islamização do ocidente.

Neste segundo artigo, o nível identificacional do texto também pode ser percebido, assim como no primeiro artigo, na necessidade de Carvalho dividir o mundo entre civilizações hostis, uma representando o bem - o ocidente cristão - e a outra o mal - o islã. Uma é a vítima, a outra o algoz. Essa construção discursiva cria e reforça identidades, ajudando a mobilizar para a luta política.

Para construir essa visão “nós” contra “eles”, é necessário imaginar um “nós” homogêneo e um “eles” também homogêneo. É uma operação discursiva que não leva em conta as heterogeneidades de ambos os lados. No caso do islã, por exemplo, desconsidera-se que as práticas políticas de grupos associados à fé islâmica são diferentes. Segundo Duarte (2015, p. 98), o islamismo contemporâneo e suas diversas formas remonta aos anos 1920, havendo uma solidificação intelectual somente após a década de 1960. O islamismo atual seria fruto desta última fase, tendo como causas a exclusão do islã durante o processo de fundação dos novos Estados-nação pós desintegração do Império Otomano e a difusão de ideologias modernas ocidentais, como o nacionalismo e o socialismo no mundo muçulmano. Haveria, portanto, três formas distintas de islamismo: a primeira de caráter 
mais político - como movimento de reação à pós-modernidade (nesse caso, tanto contra à modernidade capitalista como à socialista), à globalização e à perda de identidade, sendo um movimento de autonomia cultural e de alternativa política ou moral; a segunda tem um caráter mais missionário e não-secular; e a terceira baseia-se na revolução armada.

Segundo Duarte (2015, p. 101-104), há, entre outras, uma forma de manifestação do islamismo que busca o poder através do dinamismo do jogo político partidário, em vez do proselitismo religioso ou da ação armada. Neste caso, há inserção no jogo democrático, aceitando-se o princípio do Estado-nação e buscando a reforma e não a revolução, havendo também um notório afastamento das visões mais radicais e fundamentalistas do islão. Privilegia-se a luta por "justiça (al-adala), liberdade (al-hurriyya) e, sobretudo, de luta contra a corrupção do Estado” (DUARTE, 2015, p. 106). Assim sendo, dizer que todo o islã é associado a práticas terroristas não é correto.

Em todo o discurso de Carvalho e do MSM frente à questão muçulmana, o “nós” é construído a partir da noção de um inimigo. A ideia de inimigo a ser combatido faz parte de toda representação política de movimentos e grupos ligados à extrema-direita, pois é a suposta ameaça que estimula a mobilização nacional. Segundo Schmitt (1992, p. 51 e 52), a discriminação entre amigo e inimigo é uma distinção especificamente política a que se reportam as ações e os motivos políticos. Tal distinção teria o sentido de apontar o grau de intensidade extrema de uma ligação ou separação, associação ou dissociação. O inimigo político não precisa ser moralmente mau ou esteticamente feio, pois a diferenciação amigo-inimigo seria independente de outras distinções de caráter moral, ético, estético etc. Basta ele ser o outro, havendo em casos extremos a possibilidade de conflitos com ele, se a 
alteridade do outro representar a negação da sua própria forma de existência, devendo, assim, ser repelido e combatido para a preservação da própria forma de vida.

É importante atentar, no entanto, que, na forma de representação própria dos movimentos e pensamentos de extrema-direita, as distinções de caráter moral estão extremamente ligadas às distinções políticas, pois o outro representa sempre o mal a ser combatido, uma ameaça à integridade e à existência do “nós”. As teorias conspiratórias têm a função de dar ao inimigo um caráter maléfico e ameaçador. E para propostas políticas homogeneizantes, a existência do outro no mesmo espaço é uma ameaça à identidade e à essência do grupo, não havendo a possibilidade de coexistência com o diferente.

Cabe, então, uma discussão sobre os elementos de caráter fascista que aparecem no discurso de Carvalho. Seu discurso sobre o islamismo reitera uma visão de mundo fascista, pois é calcado na intolerância a um grupo social e religioso, na construção de imagens estereotipadas sobre este grupo e na disseminação de preconceitos em relação aos muçulmanos em geral, alimentados pela ideia de inimigos das nações ocidentais e inspirados em teorias conspiracionistas. Podemos comparar o discurso da conspiração islâmica para dominar o ocidente cristão com o discurso nazista da conspiração judaica para fins de domínio mundial. Ambos podem ser associados ao antissemitismo e à não-aceitação do outro.

Um dos autores que analisou o antissemitismo alemão, abordando as novas táticas e sua aplicação na Alemanha nazista, foi Jeffrey Herf, professor de História Moderna alemã na Universidade de Maryland, nos Estados Unidos. Segundo Herf (2014), havia uma “paranoia” nazista que afirmava a ameaça de extermínio pelo judaísmo internacional. A ideia de que os judeus queriam destruir a raça ariana e dominar 
o mundo foi disseminada através dos meios de propaganda de massa, mobilizando a sociedade alemã, tornando possíveis o preconceito, a segregação e o extermínio de milhões de judeus pelo nazismo.

Os nazistas difundiram a ideia de que os judeus eram culpados pela derrota alemã na primeira guerra mundial e os fomentadores da Segunda Guerra Mundial, havendo uma espécie de antissemitismo redentor, que combinava a paranoia sobre a comunidade judaica com as promessas de salvar a Alemanha dessa conspiração. O que eles chamavam de "judaísmo internacional” eram as supostas atuações dos judeus “por detrás dos panos”, influenciando e comandando os países contra a nação alemã. Os judeus estariam por trás tanto dos bolcheviques como dos plutocratas capitalistas que, embora fossem antagônicos, teriam a influência do judeu como “denominador comum” (HERF, 2014).

Assim como o discurso nazista, que associava os judeus ao comunismo, Carvalho e seu movimento utilizam de uma representação da realidade que associa comunismo ao islamismo, e defendem também uma teoria conspiratória, que acusa os muçulmanos de quererem eliminar a cultura cristã ocidental. Trata-se de um ideal que pode ser mobilizado pelas nações ocidentais, com base na construção de um imaginário de nação calcado nos valores do cristianismo, em oposição aos imigrantes muçulmanos, vistos como ameaça a tais valores e associados a supostos projetos de dominação mundial. A visão de mundo fascista é binária em sua essência, pois elege inimigos a serem combatidos em nome da defesa nacional ou de identidades nacionais consideradas puras e superiores. 


\section{Conclusão}

O movimento Mídia Sem Máscara, liderado por Olavo de Carvalho, contribui para disseminar o ódio e o preconceito para com os movimentos sociais associados a uma visão de mundo crítica das estruturas sociais e econômicas dominantes, utilizando de estratégias discursivas manipulatórias com o objetivo de influenciar a opinião pública de forma contrária a tais movimentos, relacionados no imaginário do autor ao "mal” que deveria ser combatido pelas nações que cultuam os valores cristãos.

A islamofobia aparece claramente em alguns textos produzidos por Carvalho e que são publicados no seu site pessoal e no site do Mídia Sem Máscara, sendo as redes sociais uma ferramenta de grande auxílio na divulgação das ideias políticas do movimento e de seu líder.

Através da escrita de artigos diversos, de cunho político-ideológico claro, o autor faz da produção de textos uma ação política, que visa a manutenção das estruturas sociais dominantes, através da persuasão sobre formas de pensar e agir dos leitores, de modo a conquistar a hegemonia na sociedade para suas ideias, calcadas numa representação binária do mundo e na construção de estereótipos acerca dos inimigos eleitos pelo grupo, entre eles, o islã e os muçulmanos.

O discurso do Mídia Sem Máscara e do seu líder, Olavo de Carvalho, é, portanto, uma prática social e política de caráter conservador, que possui elementos fascistas, devido ao seu teor intolerante, xenófobo e racista, que desumaniza o outro e o transforma em um inimigo das nações ocidentais. 


\section{Referências}

ADAMSON, W. Gramsci's interpretation of Fascism. Journal of the History of Ideas, v. 41, n. 4, p. 615-633, out.-dez., 1980.

BOBBIO, N; MATTEUCI, N \& PASQUINO, G. Dicionário de Política. Brasília: UNB, 1995.

CALIL, G. Pode o fascismo ser neoliberal? Um precedente do integralismo brasileiro. Esquerda Online, 2018. Disponível em: esquerdaonline.com.br. Acesso em 15 set. 2018.

CARVALHO, O. A Revolução Abrangente. Diário do Comércio, 27 de outubro de 2013. Disponível em: www.olavodecarvalho.org. Acesso em 01 ago. 2018.

. As garras da Esfinge - René Guénon e a islamização do Ocidente. Verbum, Ano I, Números 1 e 2, Julho-Outubro, 2016. Disponível em: www.olavodecarvalho.org. Acesso em 03 ago. 2018.

COLETTA, R. Olavo de Carvalho, o Brasil só fala dele, 2018. Disponível em: brasil.elpais.com. Acesso em 7 nov. 2019.

CHASIN, J. Sobre o Conceito de Totalitarismo. Verinotio, 15, ano VIII, abril, Rio das Ostras, 2013, p. 15-21.

COUTINHO, C. Gramsci: um estudo sobre o seu pensamento político. Rio de Janeiro: Campus, 1992.

DUARTE, F. P. O Islamismo como ideologia política de caráter secular. Relações Internacionais, 45, março, Lisboa, 2015, p. 97-110.

FAIRCLOUGH, N. Discurso e Mudança Social. Brasília: UNB, 2001.

FELICE, R. Explicar o Fascismo. Lisboa: Edições 70, 1976.

R. Revolução passiva, fascismo e americanismo em Gramsci, in INSTITUTO GRAMSCI. Política e História em Gramsci. Rio de Janeiro: Civilização Brasileira, s.d.

FINGUERUT, Ariel. A influência do pensamento neoconservador na política externa de George W. Bush. Dissertação de Mestrado, Araraquara, UNESP, 2008.

FUKUYAMA, Francis. After Neoconservatism. The New York Times, 19 de 
fev., 2006.

GRAMSCI, Antonio. Maquiavel, a política e o Estado moderno. Rio de Janeiro: Civilização Brasileira, 1989.

Antônio. Os intelectuais e a organização da cultura. Rio de Janeiro: Civilização Brasileira, 1988.

HERF, Jefrey. Inimigo Judeu. Propaganda nazista durante a Segunda Guerra Mundial e o Holocausto. São Paulo: EDIPRO, 2014.

KALIN, I. Islamophobia and the limits of multiculturalism, in: J. Esposito, I. Kalin, (eds.). Islamophobia: the challenge of pluralism in the 21st Century. Oxford: Oxford University Press, 2011. p. 3-20.

KERTZER, D. Hitler, Mussolini e o Papa. O silêncio do Vaticano e os sussurros do Duce diante da ascensão do Führer. Piauí, 126, março, 2017. Disponível em: piaui.folha.uol.com.br. Acesso em 2 out. 2018.

KONDER, L. Introdução ao Fascismo. Rio de Janeiro: Graal, 1977.

KRESS, G. Critical Discourse Analysis, in: W. G. (org.). Annual Review of Applied Linguistics, 11, 1990. p. 84-99.

LITTLE, D. American Orientalism: the United States and the Middle East since 1945. Chapel Hill: The University of North Carolina Press, 2004.

MAGALHÃES, David Almstadter. Os Think Tanks norte-americanos e a reconstrução do Iraque: divergências e convergências entre liberais e neoconservadores. Dissertação de mestrado, São Paulo, PUC, 2008.

MANDEL, E. Sobre o fascismo. Lisboa: Antídoto, 1976.

MELO, Demian B. Antonio Gramsci, Palmiro Togliatti e o consenso sob o fascismo. Revista Outubro, n. 26, julho de 2016.

MELO, I. F. Análise do Discurso e Ańalise Crítica do Discurso: desdobramentos e intersecções. Revista Eletrônica de Divulgação Científica em Língua Portuguesa, Linguística e Literatura, Ano 11, n. 5, 2009. p. 1-18.

MENDES, Lucas. Presidente Adão. Folha de São Paulo, de 22/09/2011. Disponível em: www1.folha.uol.com.br. Acesso em 17 out. 2018.

MIGUEL, Luiz F. A reemergência da direita brasileira, in: GALLEGO, E. (org.). O ódio como Política. A reinvenção das Direitas no Brasil. São Paulo: Boitempo, 2018. p. 16-26. 
MILZA, Pierre. Le Front national: droite extrême ou national-populisme?, in SIRINELLI, Jean François. Histoires des droites en france, v. 1. Paris, Gallimard, 1992.

MONDAINI, Marco. Togliatti, Gramsci e o Fascismo. 2003. Disponível em: www.acessa.com. Acesso em 08 de abril de 2019.

NEUMANN, F. Estado Democrático e Estado Autoritário. Zahar Editores: Rio de Janeiro, 1969.

NOLTE, E. Fascismo em sua Época. 1963.

PATSCHIKI, L. Os Litores da nossa Burguesia: O Mídia Sem Máscara em Atuação Partidária (2002-2011). Dissertação de Mestrado. Marechal Cândido Rondon, Universidade Estadual do Oeste do Paraná, 2012.

PAXTON, R. A Anatomia do Fascismo. São Paulo: Paz e Terra, 2007.

PINTO, P. Islã, religião e civilização: uma abordagem antropológica. Aparecida: Santuário, 2010.

PORTELLI, H. Gramsci e o bloco histórico. Rio de Janeiro: Paz e Terra, 1977.

POR QUE A DIREITA ESCOLHEU OLAVO DE CARVALHO? Outras Mídias. 11 jan. 2019. Disponível em outraspalavras.net. Acesso em: 7 nov. 2019.

POULANTZAS, N. Fascismo e Ditadura. São Paulo: Martins Fontes, 1978.

RAMOS, Guilherme Antunes. Reflexões sobre a Islamofobia nos Estados Unidos após onze de setembro de 2001: a construção discursiva da ameaça islâmica e o processo decisório em política externa. Dissertação. PósGraduação em Relações Internacionais da Universidade do Estado do Rio de Janeiro, 2015.

SAID, E. Orientalismo: o Oriente como invenção do Ocidente. São Paulo: Companhia das Letras, 2007.

SCHMITT, Carl. O Conceito do Político. Petrópolis: Vozes, 1992.

SILVA, F. C. T. Os Fascismos, in FILHO, D. A. R.; FERREIRA, J. \& ZENHA, C. (orgs.). O século XX. Vol. 2, Rio de Janeiro: Civ. Brasileira, 2003. p. 109-164.

THOMPSON, John B. Ideologia e cultura moderna: teoria social crítica na 
era dos meios de comunicação de massa. Petrópolis: Vozes, 2002.

TOGLIATTI, Palmiro. Lezioni sul fascismo, In Opere Scelte. (a cura di Gianpasquale Santomassimo). Roma: Riuniti, 1974.

TROTSKY, L. A luta contra o fascismo. Revolução e contrarrevolução. São Paulo: Editora Sundermann, 2019.

VIZENTINI, P. F. Oriente Médio e Afeganistão: um século de conflitos. Porto Alegre: Leitura XXI, 2002.

WEBER, C. International relations theory, $3^{\mathrm{a}}$ ed., New York: Routledge, 2010. 


\section{Resumo:}

O artigo analisa a islamofobia no discurso do Mídia Sem Máscara (MSM) e de seu líder, Olavo de carvalho, e sua associação com elementos do fascismo e do neoconservadorismo norte-americano, apontando sua ligação com um projeto político excludente e autoritário de extrema-direita. O MSM, fundado em 2002, faz uso das redes sociais para disseminar suas ideias, apresentando-se como "sem máscara" em oposição às mídias hegemônicas consideradas de "esquerda". A metodologia usada foi a da análise crítica do discurso, na perspectiva do linguista britânico Norman Farclough, enfatizando-se as relações entre o discurso e outros elementos da prática social. A conclusão da análise é a de que o discurso do movimento adota teorias conspiratórias acerca do islã, construindo uma visão de mundo binária entre o "bem" e o "mal”, usando como argumento a tese da islamização ocidental, com supostos pretextos de dominação mundial.

Palavras-chave: Islamofobia; fascismo; intolerância; conspiracionismo. 


\begin{abstract}
:
The article analyzes Islamophobia in the Discourse of the $M e$ dia without Mask (MSM) and its leader, Olavo de Carvalho, and its association with elements of fascism and the neoconservatism of USA, pointing out its connection with an extreme right-wing, authoritarian and exclusive political project. MSM, founded in 2002, makes use of social networks to disseminate its ideas, presenting itself as "unmasked" as opposed to hegemonic media considered as "left". The methodology used was that of the critical analysis of discourse, from the perspective of the British linguist Norman Farclough, emphasizing the relations between discourse and other elements of social practice. The conclusion of the analysis is that the movement's discourse adopts conspiracy theories about Islam, building a binary worldview between "good" and "evil," using as an argument the thesis of Western Islamization with alleged pretexts of world domination.
\end{abstract}

Keywords: Islamophobia; fascism; intolerance; conspiracy. 